\title{
Effect of full-fat rapeseed on digestibility and rumen fermentation in cattle
}

\author{
PEKKA HUHTANEN and ESKO POUTIAINEN ${ }^{1}$ \\ Department of Animal Husbandry, University of Helsinki, 00710 Helsinki
}

\begin{abstract}
The effect of whole crushed rapeseed on ration digestibility was determined with three bulls, average live weight $155 \mathrm{~kg}$, and the effect on rumen fermentation with a heifer fitted with a rumen fistula. The basal diet (B) contained $50 \%$ of grass silage and $50 \%$ of rolled barley of total DM. In experimental diets $30 \%$ of barley was replaced with crushed rapeseed fed either untreated (URS) or treated with $1.2 \%$ of Gasol solution (GRS). The feeding level was $80 \mathrm{~g} \mathrm{DM} / \mathrm{kg} \mathrm{W}^{0.75}$ for the bulls and $60 \mathrm{~g} \mathrm{DM} / \mathrm{kg} \mathrm{W}^{0.75}$ for the heifer.

The average digestibilities of the diets were 73.9 (B), 71.6 (URS) and $72.7 \%$ (GRS) for organic matter. There were no significant differences in apparent digestibility of crude protein or crude fibre. The digestibility of ether extract was higher $(\mathrm{P}<0.05)$ and that of NFE lower $(\mathrm{P}<0.01)$ on rapeseed diets. Nitrogen retentions were $28.4,30.9$ and $33.7 \mathrm{~g} / \mathrm{d}$, respectively, for the three treatments.

On rapeseed diets the rumen $\mathrm{pH}$ was higher $(\mathrm{P}<0.05)$ and the total VFA and ammonia $\mathrm{N}$ concentration lower $(\mathrm{P}<0.01, \mathrm{P}<0.05)$ than on control diet. Rapeseed increased the proportion of propionic acid $(\mathrm{P}<0.01)$ and decreased the proportion of butyric acid $(\mathrm{P}<0.01)$ in rumen VFA.

The rate of degradation of DM and CP in the rumen was slower for Gasol-treated rapeseed than for untreated rapeseed. Rapeseeds did not have a negative effect on the rate of degradation of silage or hay in the rumen determined by nylon bag method. But replacement of barley with rapeseed tended to decrease the degradation rate of silage crude protein. There were no significant differences between the treatments in blood constituents.
\end{abstract}

\section{Introduction}

There are basically two reasons for the addition of fat to the diet of ruminants: to act as an energy source and to influence the composition of the final animal product.

Dietary lipid supplements cause extensive

1 Present address: Agricultural Research Centre, SF-31600 Jokioinen. modification to digestion in the rumen. Fats have been reported to inhibit the fermentation, particularly of crude fibre (PALMQVIST and JENKINS 1980), which leads to reduced intake of roughages (KowALCZYK et al. 1977). There is a change in the acetate/propionate ratio (PALMQViST and JENKINS 1980, IGWUEGBU and SutTON 1982) and hydrogenation of polyunsaturated fatty acids decreases

Key words: fat, rapeseed, digestibility, rumen fermentation, blood composition 
methanogenesis in the rumen because of the competition from hydrogen (CZERKAwSKI and Clapperton 1984). KowalczyK et al. (1977) reported decreased ammonia concentration in the rumen with successive tallow increments. Lipid supplements in the diets have also been shown to increase the efficiency of microbial protein synthesis in the rumen (TAmminga et al. 1983, Sutton et al. 1983).

The negative effects of fats on fibre digestibility can be reduced by feeding them as natural unextracted oilseeds or in various protected forms (STORRY 1980). PAlmQvist and JENKINS (1980) reported that caicium improves fibre digestibility in high fat diets by forming insoluble soaps. Full fat oilseeds have mainly been used for dairy cows: for example, crushed soyabeans (STEELE et al. 1971), whole cottonseed (Sмiтн et al. 1981), whole sunflower seed (RAFALOWSKI and PARK 1982) and rapeseed (FranK 1979). Murphy et al. (1984) studied the effect of rapeseed on rumen and total digestibility in dairy cows.

The objective of this study was to examine the effect of crushed rapeseed, fed as untreated or Gasol-treated, on ration digestibility, rumen fermentation and blood composition in growing cattle.

\section{Material and methods}

Three Ayrshire bulls, aged 3 months and weighing approximately $110 \mathrm{~kg}$ at the beginning of the experiment, were used as experimental animals in the digestibility trial. A heifer fitted with a rumen fistula was used for rumen fermentation and in sacco studies. All the animals were kept in metabolism cages allowing a separate collection of faeces and urine.

The experiment was designed as a $3 \times 3$ Latin square. The digestibility trial consisted of transition, palatability, adaptation and collection periods lasting 4, 5, 5 and 7 days, respectively. The basal ration (B) consisted of grass silage ( $50 \%$ of DM) and rolled barley $(50 \%$ of DM), of which $30 \%$ was re- placed in experimental diets with untreated (URS) or Gasol-treated rapeseed (GRS). Gasol solution, which contains organic acids and formaldehyde, was used at a level of $1.2 \%$. In addition the animals received a commercial mineral mixture (Kulta-Tuotos) $100 \mathrm{~g} / \mathrm{d}$ and water freely. The feeding level was $80 \mathrm{~g}$ $\mathrm{DM} / \mathrm{kg} \mathrm{W}^{0.75}$ for the bulls and $60 \mathrm{~g} \mathrm{DM} / \mathrm{kg}$ $\mathrm{W}^{0.75}$ for the heifer. During the palatability period the bulls received concentrate $40 \mathrm{~g}$ $\mathrm{DM} / \mathrm{kg} \mathrm{W}^{0.75}$ and grass silage ad libitum. The daily diets were given in two equal proportions at 8 and 15 hours. The bulls were weighed before and after the collection periods.

The faeces were collected twice daily and urine in the morning. Representative samples were taken for analysis and frozen. DM determinations were made at $103^{\circ} \mathrm{C}$; the samples for analysis were dried in vacuum at $50^{\circ}$ $\mathrm{C}$ and milled through a $1-\mathrm{mm}$ screen. Feed analyses were made according to standard methods. In vitro digestibility of grass silage was measured according to the method of Tilley and Terry (1963). Ammonia nitrogen (McGullough 1967), lactic acid (PARKER and Summerson 1941) and VFA contents of grass silage (HuIDA 1973) were determined later from deep-frozen samples.

In rumen fermentation and in sacco studies the heifer was in the 1st period on treatment $\mathrm{B}$ and in the 2 nd and 3rd periods on treatments URS and GRS. Rumen fluid samples were taken through the fistula before and $1.5,3,4.5$ and $6 \mathrm{~h}$ after the morning feeding on days 6 and 7 during the collection period. pH was measured immediately and ammonia $\mathrm{N}$ and VFA determinations were made from deep-frozen supernatant by the methods of Mcgullough (1967) and Huida (1973).

The degradation rate of DM and crude protein (CP) of rapeseeds were determined by nylon bag method (SETÄLÄ 1983) in each period. The incubation times were 2, 5, 9 and $24 \mathrm{~h}$. In addition it was investigated whether the diets might affect the rate of digestion of grass silage and hay in the rumen. Nylon 
Table 1. Chemical composition of experimental feeds.

\begin{tabular}{lccrrrr}
\hline & Dry matter, \% & \multicolumn{3}{c}{ In dry matter, \% } \\
\cline { 3 - 7 } & & Ash & $\begin{array}{c}\text { Crude } \\
\text { protein }\end{array}$ & $\begin{array}{c}\text { Ether } \\
\text { extract }\end{array}$ & $\begin{array}{c}\text { Crude } \\
\text { fibre }\end{array}$ & NFE \\
\hline Silage & 26.8 & 6.6 & 16.4 & 6.0 & 27.5 & 43.5 \\
Barley & 88.5 & 2.8 & 11.0 & 2.4 & 5.2 & 78.5 \\
Untreated rapeseed & 92.4 & 5.1 & 23.1 & 37.5 & 10.4 & 23.9 \\
Treated rapeseed & 92.3 & 5.2 & 23.3 & 36.8 & 10.4 & 24.3 \\
\hline
\end{tabular}

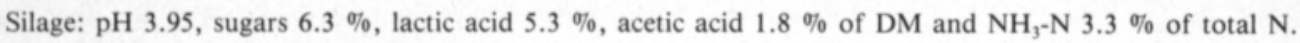

bags were withdrawn after 2, 5, 9 and $24 \mathrm{~h}$ for both forages and in addition after $48 \mathrm{~h}$ for hay.

Blood samples were taken from the bulls from the Vena jugularis at the beginning of the experiment and on the 7th day of the collection period before the morning feeding. The samples were prepared and analyzed by the methods described by HuhtanEn (1984).

The differences between the treatments were tested by the analysis of variance and the differences between the means with the Tukey-test.

\section{Results and discussion}

Chemical composition of the experimental feeds is presented in Table 1. Grass silage was of very good quality, D-value 70.4 , and well preserved. The average contents of ether extract were $4.1,9.4$ and $9.3 \%$ for diets B, URS and GRS.

Rapeseed had no significant effect on total DM intake during the palatability period. The average DM intakes were 96.1. 96.8 and $91.4 \mathrm{~g} \mathrm{DM} / \mathrm{kg} \mathrm{W}^{0.75}$ for the treatments B, URS and GRS. The highest forage intake was obtained on URS treatment because the bulls did not eat all the concentrate and compensated for this by increasing silage intake. The effect of added fat on voluntary feed intake of sheep and cattle seems according to Clapperton and Steele (1983) to depend on the type and amount of fat used and the way in which it is added. SмITH et al. (1981) and RAFALOWSKI and PARK (1982) did not find whole cottonseed or whole sunflower seed to have any effect on DM intake in dairy cows. In contrast, Thomas and CASTLe (1979) reported lower grass silage intake when the supplemental fat was fed as crushed soyabeans instead of soya oil.

OM digestibilities of rapeseed rations were slightly lower than the digestibility of the basal ration (Table 2). Replacement of barley with URS or GRS improved $(\mathrm{P}<0.05)$ ether extract digestibility, an effect also found by Palmqvist and Conrad (1978), Smith et al. (1981) and van der HoNIG et al. (1981) with various types of added fats. In contrast, MurPHY et al. (1984) reported lower total fatty acid digestibility with increasing levels of rapeseed in the diet. The reason for lower $(\mathrm{P}<0.01)$ NFE digestibility for rapeseed diets may be that the NFE fraction in rapeseed is less digestible the NFE fraction in barley, which contains more starch. The digestibility coefficients of URS, calculated by difference, were $71.2,88.8,92.9$ and $44.4 \%$

Table 2. Ration digestibility and nitrogen retention.

\begin{tabular}{lllll}
\hline Diet & B & URS & GRS & SEM \\
\hline Dry matter & 71.8 & 69.6 & 70.9 & 0.4 \\
Organic matter & 73.9 & 71.6 & 72.7 & 0.4 \\
Crude protein & 60.8 & 65.1 & 63.4 & 1.5 \\
Ether extract & $72.7^{\mathrm{b}}$ & $83.9^{\mathrm{a}}$ & $82.0^{\mathrm{a}}$ & 0.8 \\
Crude fibre & 59.3 & 59.8 & 60.5 & 1.6 \\
NFE & $80.7^{\text {ad }}$ & $75.8^{\text {ce }}$ & $78.6^{\text {bde }}$ & 0.3 \\
N retention g/d & 28.4 & 30.9 & 33.7 & 2.0 \\
$\quad \%$ of intake & 36.2 & 36.4 & 37.8 & \\
$\quad \%$ of absorbed & 59.6 & 56.0 & 59.7 & \\
\hline
\end{tabular}

SEM = standard error of means. Means with different letters significantly different a,b,c, $(\mathrm{P}<0.05)$, d,e $(\mathrm{P}<0.01)$ 
for $\mathrm{OM}, \mathrm{CP}$, ether extract and crude fibre (CF), and those of GRS 74.7, 79.0, 89.2 and $52.4 \%$, respectively. The values for CP and ether extract are comparable to those presented in Finnish feed tables (Salo et al. 1982) but the value for OM and is lower and that for CF higher.

The apparent digestibility of CP tended to be higher on URS and GRS diets than on the basal diet. One reason for higher apparent $\mathrm{CP}$ digestibility on rapeseed diets is the higher CP content. Gasol treatment had a clear effect on CP degradability of rapeseed (Fig. 1). However, there was no overprotection because Gasol treatment decreased only slightly the apparent $\mathrm{N}$ digestibility in the whole tract.

Rapeseed did not have a negative effect on CF digestibility. The rate of digestion of hay tended to be higher on rapeseed diets (Fig. 2). In contrast, MurPHy et al. (1984) repor-

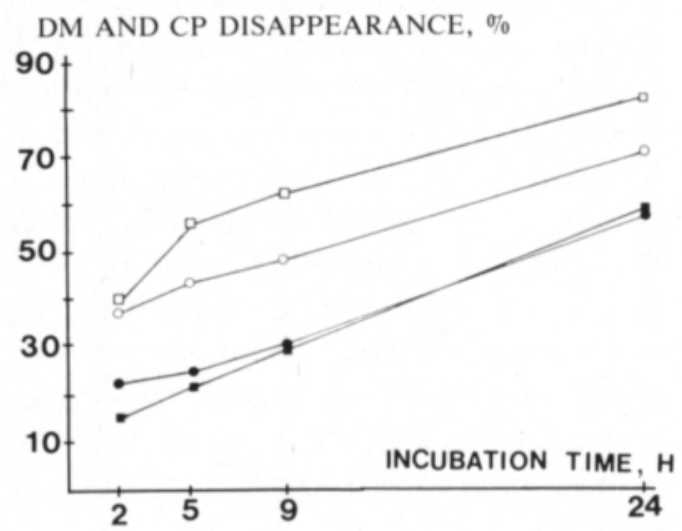

Fig. 1. The effect of Gasol treatment on DM and CP degradation of rapeseed in the rumen (DM: $\mathrm{O}$ untreated, - treated, CP: $\square$ untreated, treated)

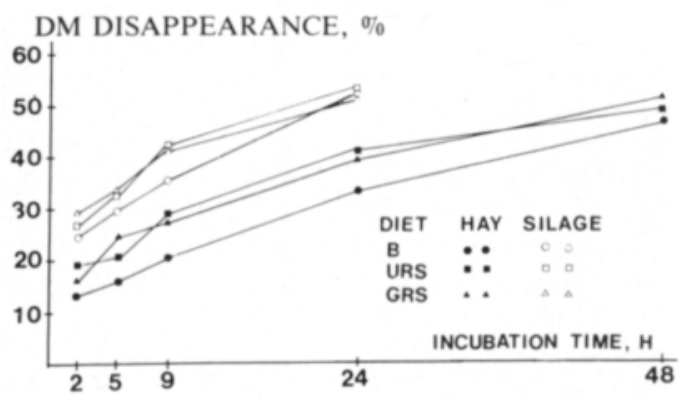

Fig. 2. The effect of the experimental diets on degradation of hay and silage DM in the rumen ted lower cellulose digestibility in the rumen on rapeseed diets, and a tendency for lower rumen digestibility of NDF and total digestibility of cellulose and NDF. In their study, however, rapeseed replaced a concentrate mixture containing $35 \%$ of barley and oats and $30 \%$ of oilseed meals, which do not have so great an effect on digestion of fibre in the rumen as the starch-rich barley used in the present study. Likewise KowAlczYK et al. (1977) and ØRSKOv et al. (1978) reported a lower rate of digestion of forage when fat increments were used on grass diets. PALMQvist and ConRAD (1978) suggested that the negative effects of high starch diets can be reduced by using fat to replace energy from starch in isocaloric diets. The increased intake of good quality protein in our experiment may also have contributed to the fact that the higher fat intake did not have a negative effect on forage digestibility in the rumen (Mcallan and Smith 1983). Rapeseeds tended to decrease the degradation rate of silage crude protein. The same tendency was found by IGwUEgBu and Sutton (1982) with linseed oil in sheep with duodenal cannulas.

The negative effects of fats and oils on fibre digestibility have often been reported in sheep (KowalczyK et al. 1977, Mcallan et al. 1983, Sutton et al. 1983) and the lipids tend to shift the site of digestion of OM from the rumen to the hind gut (Igwuegbu and SutTon 1982). The effect of oils on fibre digestion in the rumen can be reduced by protecting them from microbial metabolism (Mcallan et al. 1983). In dairy cows, the effects of fats on fibre digestibility have often been less than in sheep due to high feed intakes and low rumen retention times (PALMQvisT and JENKInS 1980). In the present study the feeding level was about twice the maintenance and much higher than typically used in the experiments with sheep. Also the method by which the lipids are incorporated into the diet can affect fibre digestibility. SMiтH et al. (1981) did not find any effect on cellulose digestibility when complete rations contained 
up to $25 \%$ whole cottonseed. When soyabean oil was given as cracked soyabeans instead of free oil, rumen fermentation was less affected, because the milk fat content was higher on cracked soyabean diet (STEELE et al. 1971).

In the present study URS and especially GRS tended to increase nitrogen retention. One reason for this may be the increased microbial protein synthesis (MPS) on rapeseed diets (MurPhy et al. 1984), but also an increased flow of undegradable feed protein may have had an effect, especially in the case of the GRS diet. In many experiments, lipid supplements have been shown to increase the efficiency of MPS (Igwuegru and Sutton 1982, Tamminga et al. 1983, Sutton et al. 1983), possibly by their protozoa-inhibiting effect (Sutton et al. 1983). The total effect of fats on microbial protein production in the rumen depends, however, in addition to the efficiency of MPS, on the effect of fats on feed intake and the proportion of OM digested in the rumen.

Rumen $\mathrm{pH}$ was higher on GRS ration than on basal ration (Table 3), and this, too, may have affected the fibre digestion in the rumen. Also KowalczYK et al. (1977) found higher rumen $\mathrm{pH}$ with increasing tallow supplements on grass diet. MURPHY et al. (1984) did not find any significant differences in rumen $\mathrm{pH}$ in their diets, but the composition of concentrate was different

Table 3. $\mathrm{pH}$, ammonia $\mathrm{N}$ and volatile fatty acids in the rumen fluid. The values are means of different sampling times.

\begin{tabular}{lcccl}
\hline Diet & B & URS & GRS & SEM \\
\hline pH & $6.08^{\mathrm{a}}$ & $6.37^{\mathrm{ab}}$ & $6.52^{\mathrm{b}}$ & 0.10 \\
Ammonia N, mmol/1 & $9.71^{\mathrm{a}}$ & $4.50^{\mathrm{b}}$ & $5.50^{\mathrm{ab}}$ & 1.42 \\
Total VFA, mmol/1 & $118.6^{\mathrm{d}}$ & $92.7^{\mathrm{e}}$ & $89.8^{\mathrm{e}}$ & 4.7 \\
Molar \% of & & & & \\
$\quad$ Acetic acid & 63.7 & 62.9 & 61.9 & 0.9 \\
Propionic acid & $14.4^{\mathrm{d}}$ & $22.6^{\mathrm{e}}$ & $26.3^{\mathrm{f}}$ & 0.7 \\
Butyric acid & $18.5^{\mathrm{d}}$ & $11.2^{\mathrm{e}}$ & $8.6^{\mathrm{f}}$ & 0.4 \\
C5 and C6 total & 3.5 & 3.3 & 3.2 & 0.1 \\
\hline
\end{tabular}

Means with different letters were significantly different a,b,c $(\mathrm{P}<0.05)$, d,e,f $(\mathrm{P}<0.01)$ than in the present study. The total VFA level was lower $(P<0.01)$ on URS or GRS rations than on $\mathrm{B}$ ration. The same tendency was found by MurPHY et al. (1984), but not by Igwuegru and Sutton (1982) on linseed oil supplements. The lower concentration of ammonia $\mathrm{N}$ in the rumen on rapeseed diets in spite of the higher crude protein intake agrees with the results of KowALCZYK et al. (1977) and Igwuegbu and Sutton (1982).

The proportion of acetic acid in VFA was not significantly different in the diets, but the proportion of propionic acid was higher $(\mathrm{P}<0.01)$ and that of butyric acid lower $(\mathrm{P}<0.01)$ on rapeseed rations. In many experiments, lipid supplements have also decreased the proportion of acetic acid (STEELE et al. 1971, RoHr et al. 1978, Sutton et al. 1983), although RAFALOwSKI and PARK (1982) found whole sunflower seed to increase the proportion of acetate. A similarly large decrease in the proportion of butyric acid as in the present study was found by IGWUEGBU and Sutton (1982) and Sutton et al. (1983). STEELE et al. (1971) reported that the effect of soya oil on the acetate/propionate ratio was less when the oil was fed as cracked soyabeans instead of free oil. The increase in propionate/butyrate ratio and the lower ammonia $\mathrm{N}$ concentration on rapeseed rations indicate the inhibitory effect of full-fat rapeseed on protozoa (Males and Purser 1970); this was also found by SutTon et al. (1983) for linseed oil supplements.

The only significant $(\mathrm{P}<0.05)$ difference in blood composition was higher $\mathrm{Na}$ concentration on rapeseed rations (Table 4). Plasma urea tended to be lower on GRS than on B or URS ration. Plasma glucose and cholesterol concentrations were slightly higher on the rapeseed rations. Igwuegru and SutTON (1982) and CHRISTENSEN et al. (1978) reported lower plasma urea $\mathrm{N}$ when linseed oil or whole rapeseed was used for ruminants, and CHRISTENSEN et al. (1978) reported higher cholesterol concentration on diets containing 6.3 or $12.6 \%$ of rapeseed of concentrate 
Table 4. The effect of diets on blood composition.

\begin{tabular}{lcccc}
\hline Diet & B & URS & GRS & SEM \\
\hline Haemoglobin, g/1 & 113 & 120 & 114 & 1.7 \\
In plasma: & & & & \\
Glucose, mmol/1 & 5.45 & 5.63 & 5.71 & 0.10 \\
Total protein, g/1 & 61.3 & 61.0 & 62.0 & 1.2 \\
Albumin, g/1 & 34.7 & 33.7 & 33.7 & 0.9 \\
Urea, mmol/1 & 1.77 & 1.99 & 1.23 & 0.36 \\
Creatinine, mmol/1 & 121 & 105 & 107 & 21 \\
Cholesterol, mmol/1 & 3.23 & 3.57 & 3.53 & 0.82 \\
AP, IU/1 & 359 & 398 & 402 & 23 \\
ALAT, IU/1 & 14.3 & 18.7 & 17.3 & 1.4 \\
ASAT, IU/1 & 54.3 & 59.0 & 57.0 & 3.2 \\
Inorg. P, mmol/1 & 3.11 & 3.12 & 2.85 & 0.24 \\
Ca, mmol/1 & 2.60 & 2.60 & 2.73 & 0.05 \\
Mg, mmol/1 & 0.93 & 0.94 & 0.96 & 0.03 \\
Na, mmol/1 & $138^{\mathrm{a}}$ & $140^{b}$ & $140^{b}$ & 0.2 \\
$\mathrm{~K}, \mathrm{mmol} / 1$ & 47.0 & 45.3 & 46.7 & 1.5 \\
\hline
\end{tabular}

Means with different letters significantly different a,b $(\mathrm{P}<0.05) . \quad \mathrm{AP}=$ alkaline phosphatase. $\mathrm{ALAT}=$ alanine aminotransferase. ASAT $=$ asparte aminotransferase. mixture. In the present study, the plasma cholesterol in the same bulls fed barley and grass silage diet before the experiment was only about $50 \%$ of that found during the experiment.

In summary, crushed rapeseed used at a level of $30 \%$ of concentrate $(15 \%$ of the total DM) did not have a negative effect on ration digestibility and tended to increase $\mathrm{N}$ retention in growing bulls when it replaced barley in the diet. Because of the very large shifts in VFA proportions, further experiments are needed to evaluate the effect of whole rapeseed at this high level in dairy cow diets.

Acknowledgements. This study was made possible by the support of the Farmos Co. The authors wish to thank Miss Leena Kukkula for technical assistance.

\section{References}

Barker, S.B. \& Summerson, W.H. The colorimetric determination of lactic acid in biological material. J. Biol. Chem. 138: 535-554.

Christensen, D.A., Steaacy, G. \& Cochran, M. 1978. Utilization of protected and unprotected rapeseed by lactating dairy cows. Proc. 5th Int. Rapeseed Conf. Vol. 2. pp. 217-219. Malmö.

Czerkawski, J.W. \& Clapperton, J.L. 1984. Fats as energy yielding compounds in the ruminant diet. Fats in animal nutrition. Ed. Wiseman, J. p. 249-263. Butterworths.

Frank, B. 1979. Fatty rape products for dairy cows. 1. Rapeseed in a straw based diet. Report 70. Swedish University for Agricultural Science, Department of Animal Husbandry. Uppsala.

Honig, Y. van der, Wieman, B.J., Steg, A. \& DonseLAAR, B. van. 1981. The effect of fat supplementation of concentrates on digestion and utilization of energy by productive dairy cows. Neth. J. agric. Sci. 29: 79-92.

Huhtanen, P. 1984. Wood molasses as a preservative for high moisture barley. 3. Feeding value foe growing cattle. J. Agric. Sci. Finl. 56.

HuIDA, L. 1973. Haihtuvien rasvahappojen kvantitatiivinen mäărittäminen pötsinesteestä ja săilörehusta kaasukromatografisesti. J. Scient. Agric. Soc. Finl. 45: $485-488$.
Ikwuegbu, O.A. \& Sutton, J.D. 1982. The effect of varying amount of linseed supplementation on rumen metabolism in sheep. Brit. J. Nutr. 48: 365-375.

Kowalczyk, J., Ørskov, E.R., Robinson, J.J. \& StewarT, C.S. 1977. Effect of fat supplementation on voluntary intake and rumen metabolism in sheep. Brit. J. Nutr. 37: 251-257.

Males, J.R. \& Purser, D.B. 1970. Relationship between rumen ammonia level and microbial population and volatile fatty acid proportions in faunated and defaunated sheep. Appl. Microb. 19: 485-490.

McAllan, A.B. \& Swith, R.H. 1983. Effect of dietary nitrogen supplementation on fibre digestion in the rumen. Proc. Nutr. Soc. 42: 50A.

— \& KNight, R. \& Sutton, J.D. 1983. The effect of free and protected oils on the digestion of dietary carbohydrates between the mouth and duodenum of sheep. Br J. Nutr. 49: 433-440.

McGullough, H. 1967. The determination of ammonia in whole blood by a direct colorimetric method. Clin. Chem. Acta 17: 297-304.

Murphy, M., Uden, P., Palmowist, D.L. \& WiktorsSON, H. 1984. Rumen and total digestibilities in lactating cows fed diets containing full-fat rapeseed. Paper presented at the 35th Annual Meeting of EAAP. The Hague.

Ørskov, E.R. Hine, R.S. \& GrubB, D.A. 1978. The effect of urea on digestion and voluntary intake by 
sheep of diets supplemented with fat. Anim. Prod. 27: 241-245.

Palmevist, D.L. \& Conrad, H.R. 1978. High fat rations for dairy cows. Effect on feed intake, milk and fat production and plasma metabolites. J. Dairy Sci. 61: $890-901$.

- \& Jenkins, T.C. 1980. Fat in lactation rations: Review. J. Dairy Sci. 63: 1-14.

RAFAlowsK1, W. \& PARK, C.S. 1982. Whole sunflower seed as a fat supplement for lactating cows. J. Dairy Sci. 65: 1484-1492.

Rohr, K., Daenicke, R. \& Oslage, H.J. 1978. Untersuchungen über den Einfluss verschiedener Futtermischungen auf Stoffwechsel und Leistung von Kühen. Lantbauforschung Völkenröde 28: 139-150.

Salo, M-L., Tuori, M. \& KiISKInen, T. 1982. Rehutaulukot ja ruokintanormit. 70 p. Helsinki.

Smith, N.E., Collar, L.S., Bath, D.L., Dunkley, W.L. \& Frank, A.A. 1981. Digestibility and effects of whole cottonseed fed to lactating cows. J. Dairy Sci. 64: 2209-2215.

Steele, W., Noble, R.C. \& Moore, J.H. 1971. The effect of 2 methods of incorporating soyabean oil into

\section{SELOSTUS}

\section{Rypsinsiemenen vaikutus rehun sulavuuteen ja pötsifermentaatioon märehtijällä}

\author{
Pekka Huhtanen ja Esko Poutiainen ${ }^{1}$ \\ Helsingin yliopisto, kotieläintieteen laitos, \\ 00710 Helsinki 71
}

Murskatun rypsinsiemenen vaikutusta rehuannoksen sulavuuteen tutkittiin kolmella sonnilla, joiden elopaino oli keskimäărin $155 \mathrm{~kg}$, ja pötsifermentaatioon fistelöidyllä hieholla. Perusdieetti (I) koostui $50 \%$ :sta nurmisăilörehua ja $50 \%$ :sta ohraa kuiva-aineesta. Koedieeteissă $30 \%$ ohran kuiva-aineesta korvattiin murskatulla rypsinsiemenellă, joka annettin joko käsittelemăttömănă (II) tai kăsiteitynă $1.2 \%$ :lla Gasol-liuosta (III). Ruokintataso oli sonneilla $80 \mathrm{~g} \mathrm{ka} / \mathrm{kg} \mathrm{W}^{0.75}$ ja hieholla $60 \mathrm{~g}$ $\mathrm{ka} / \mathrm{kg} \mathrm{W}^{0.75}$.

Rehuannoksen orgaanisen aineen sulavuus oli 73.9 71.6 ja $72.7 \%$ ruokinnoilla I, II ja III. Raakavalkuaisen ja -kuidun nảennäisessă sulavuudessa ei ollut eroa ruokintojen välillä. Raakarasvan sulavuus oli parempi $(\mathrm{P}<0.05)$ ja typettömiem uuteaineiden huonompi $(\mathrm{P}<0.01)$ rypsinsiementä sisältävillă ruokinnoilla. Typpitase oli ruokinnoilla I, II ja III 28.4, 30.9, ja $33.9 \mathrm{~g} / \mathrm{pv}$. the diet on milk yield and milk composition in dairy cow. J. Dairy Res. 38: 43-48.

StorRY, J.E. 1981. The effect of dietary fat on milk composition. Recent advances in animal nutrition. Ed. Haresign, W. p. 3-33. Butterworths.

Sutton, J.D., Knight, R., McAllan, A.B. \& Sмith, R.H. 1983. Digestion and synthesis in the rumen of sheep given diets supplemented with free and protected oils. Br. J. Nutr. 49: 419-432.

Tamminga, S., VuUren, A.M. van, Koelen, C.J. van, KтAтtAB, H.M. \& Gils, L.G.M. van. 1983 Further studies on the effect of fat supplementation of concentrates for dairy cows. 3. Effect on rumen fermentation and sites of digestion of dietary components. Neth. J. agric. Sci. 31: 249-258.

Thomas, P.C. \& Castle, M.E. 1979. The work of the nutrition and metabolism and dairy husbandry sections of applied studies departments. Rep. Hannah Res. Inst., 1978. pp. 108-117.

Tilley, J.M. \& Terry, R.A. 1963. A two stage technique for the in vitro determination of forage crops. J. Br. Grassl. Soc. 18: 104-111.

Ms received January 3, 1985
Perusdieetillă pötsinesteen $\mathrm{pH}$ oli alempi $(\mathrm{P}<0.05)$, VFA:n kokonaismäärä ja ammoniakkipitoisuus korkeampi $(\mathrm{P}<0.01, \mathrm{P}<0.05)$ kuin II- ja III dieeteillă. Rypsinsiemen lisäsi propionihapon $(\mathrm{P}<0.01)$ ja vähensi voihapon osuutta $(\mathrm{P}<0.01)$ pötsinesteen VFA:sta.

Rypsinsiemenen Gasol-käsittely alensi sen kuivaaineen ja raakavalkuaisen hajoamisnopeutta pötsissä. Kummallakaan rypsinsiemenellă ei ollut negatiivista vaikutusta heinän tai săilörehun hajoamisnopeuteen pötsissả nailonpussimenetelmällä määritettynä. Ohran korvaaminen rypsillă năytti alentavan säilörehun valkuaisen hajoamisnopeutta pötsissä.

\footnotetext{
1 Nykyinen osoite:

Maatalouden tutkimuskeskus

31600 Jokioinen
} 